\title{
FUTURE ETHICAL CHALLENGES AS PORTRAYED IN SCIENCE FICTION FILMS
}

Fictional worlds of sci-fi films are but visions of the stage humanity (and the world) is coming to given the ever-evolving technological progress. On the one hand, there are optimistic views of scientific development, on the other, there are ethical warnings, especially when a film portrays consequences for humanity and the planet; a vision, in which we crossed the boundaries and fundamentally change the nature of living organisms either by changing their genetic information, or by implanting nanotechnologies. Therefore, the present article reflects on some ethical challenges portrayed in sci-fi films; in particular, we especially concentrate on the meeting point of ethics and religion.

Keywords: sci-fi, ethics, futurology, religion

\section{Introduction}

There are times in everyone's life when one is drawn to think more about his or her future - and future of the life on Earth. What is awaiting us, what will we experience during our life and where do we go? Religion, science and the culture in which one grows and lives certainly have an impact on the person's image of the future. The vision of the future is also inspired by sci-fi literature and films: they are based on what we know so far and intuitively present possible future scenarios.

Animated images - with suggestive music - create a fictional world of metaphors, codes, ciphers, and symbols that evoke questions about the transcendence of being. A film can express the reality directly by, say, a theme linked to a particular ethical or religious worldview - or hide it in the secular reality of the contemporary world [1]. There are also burning ethical questions one could have asked if potential future scenarios were to be considered.

We concentrate on the precursors of the moral conflict between good and evil - a rather popular theme in science fiction films. Therefore, we should explore the concept shortly. In this article, we note three moments that can fundamentally change the future of mankind and the whole planet. It is always a warning based on an apocalyptic scenario: a certain alternative version of the biblical 'beast' from the Book of Revelation is unleashed - either in the form of a modified human being or animal, or a self-confident and super-powerful artificial intelligence. From this perspective, the ethical issues concern interference with human and animal nature to create a perfect species or to give 'free will' to the products of an advanced technology, which, as a rule, gain self-centered awareness and begin to regard humans as their enemies.

The Book of Revelation (New Testament) has been an inspiration for literary and artistic creation throughout our history [2]. It presents the final moments of the eternal fight with a mysterious figure - 'the beast'. The beast performs miracles and people adore it for that. Its power is further reinforced by the second earthly 'beast': a false prophet [3]. This character, which abuses power over others through magical power, appears throughout the Bible in various forms [4].

It is rather obvious that the description of the celestial struggle the author of the Book of Revelation gives is based upon his experience of persecution by adherents of the cult of the Emperor. Clearly, it is a general call to alertness for future generations of Christians not to adore a man possessed by power, manipulation, and violence. Throughout history, many Christians have projected this spiritual background of despotic power into a particular historical figure, pointing to the possible signs of the end of times.

Leaving this chiliastic perspective aside, the question arises as to whether the behavior of certain characters in sci-fi films in their symbolism (a super-powerful artificial intelligence creature or a lab-produced person with a supernatural consciousness) are not to be seen as analogous to the apocalyptic images of the 'beast': both require worship by subordinate people. It is this phenomenon that we look at in the following sections. In a certain

\footnotetext{
* Karel Sladek

Department of Theological Ethics and the Spiritual Theology, Catholic Theological Faculty, Charles University in Prague and Center for Applied Ethics, Catholic Theological Faculty, Charles University in Prague, Czech Republic

Email: sladek@ktf.cuni.cz
} 
way, then, the ethical warning of sci-fi films turns into a religious problem after all.

\section{The arrival of a technologically superior Superman}

One of the worries often portrayed in the sci-fi genre is the arrival of a genetically (or in other way improved, often with reference to nano-technology) enhanced being that starts to 'reproduce' himself. Multiplied in such a way, he tries to control the rest of mankind. This kind of ethical question is shown in several of the Star Trek episodes.

The issue of manipulation with human genetic information is depicted in Star Trek II: The Wrath of Khan [5] and his cloning in Star Trek X: Nemesis [6]. Individuals 'manufactured' in such a way have a strong propensity for elitism, egoism, and violence.

The possibility of creating life in a laboratory is featured as a promising experiment (with just a dash of doubts) in Star Trek II: The Wrath of Khan: within a few days, a group of scientists creates life on a desolate planet - as if copied from Genesis ( $\mathrm{Gn}$ 1, 1-31). The whole enterprise doesn't last long though: already at the beginning of Star Trek III: The search for Spock [7] it ends with disaster and a rapid end of the artificially created life.

From an ethical point of view, testing whether manipulation of human nature brings about the arrival of a technologically advanced Superman, raises an important question: the question whether the individual's creative freedom and ability to freely form relationships with others is preserved.

The Star Trek fictional world presents yet another ethical challenge (which turns out to be quite the opposite of the intended improvement of life quality); this challenge reappears both in Star Trek: The Next Generation and Star Trek: First Contact [8]. It is in these episodes where the so-called Borg appears. The Civilization of the Borg decided to conquer the world. They share consciousness and their aim is expressed by the phrase (paraphrased in various versions to address different races in the universe): 'We are the Borg. Your biological and technological distinctiveness will be added to our own. Resistance is futile'.

In the TV series, even the Captain Jean-Luc Picard of the starship Enterprise is assimilated and becomes one of the Borgs - he is enhanced with biomechanical components implanted with nanotechnology. Thus, he is transformed into Locutus of Borg. After his liberation from the Borgs, he has to go through a painful cleansing 'detox' of the mind: he has to regain consciousness of his own identity and the ability to freely decide for the good.

The structure of the Borg civilization is analogous to the sectarian hierarchy: personal individuality is destroyed in the mindless acceptance of the views of the absolute authority, the leader. The world of the Borgs is clearly divided between the good (that is, Borgs) and evil (other civilizations that need to be assimilated to Borg). Borgs don't ask questions, they just give simple answers and solutions (assimilation). They cannot enter into a dialogue; they can just fight and incorporate others into their system. The borders of the Borg Empire are considered to be the limit of 'truth' - and the truth must keep conquering the world. The Borg community brings a seeming sense of security, as it gives its members perfect care. After all, that is rather similar to various religious and political totalitarian sects [9].

In Star Trek: Voyager, these cyborgs strive to get the perfect 'omega molecule'. The Omega is associated with the resurrected Christ in the Christian symbolism (Rev 1,$8 ; 21,6 ; 22,13)$ and it is personified cosmic energy that attracts everything alive to the fullness of being. In the Star Trek fiction world, the Borgs try to produce the 'omega molecule' artificially - since they want to employ its power in their despotic plan to subdue other civilizations. They strive to discover the perfectly harmonious and stable molecule that would help them to develop further. Humanity attempts to stop the experimentation with the 'omega molecule' by all means.

This mysterious 'omega molecule' is a code to understand the text in a biblical perspective. There are the similarities of the Beast Empire of the Book of Revelation with the fictional world of the saga: through the symbols of totalitarian power, it depicts an intelligent creature - a kind of a hybrid between a living being and a machine. The intelligent creature dictates a collective consciousness to everybody, and unconditional adoration of the power and the system is required.

Therefore, it is natural to ask whether improving human nature (notice, however, that only the rich could afford these improvements) wouldn't necessarily lead to the creation of a new species that - in turn - would despise (the original imperfect) human nature. Should this indeed happen, the inevitable follows: the end of humanity and the destruction of the essential quality of human freedom and love, as gained from the Creator.

\section{The pitfalls of genetic and biochemical 'enhancement' of animals}

Another ethical challenge is the possibility of nature-changing genetic manipulation and experimentation on animals. Many cult films of the 1960s and 1970s get new remakes now - or prequels. It is often the case that the new possibilities of the $3 \mathrm{D}$ format are more important than the idea of the script; nevertheless, the idea that behind the fictional worlds of films about the future there is a man (or a man-made machine) is still there.

It is worth mentioning the relatively successful prequel (Rise of the Planet of Apes [10]) to the film Planet of the Apes [11], which in turn started a series of other film variations on the conflict between humans and intelligent apes. The first prequel was soon followed by Dawn of the Planet of the Apes [12] and further by War for the Planet of the Apes [13]. The saga is apparently still kept going on, and it is gaining ever more fans even in the present generations. 
The film Rise of the Planet of the Apes questions - again - the relationship between man and animal. It seeks to clarify the moment reasoning first appeared in apes. According to the film storyline (which, by the way, has the ambition to present the current reality as much as possible), increased intelligence was first identified in the young chimpanzee Caesar. Caesar's parents were apes on which new medicine against Alzheimer's disease was tested. Scientist Will Rodman decided to administer the tested medicine to Caesar secretly, despite the fact that the project was abolished, as its side effects increased aggression in the tested animals. The drug-induced changes in the brain structure also led to increased intelligence, and a bright mind and the ape's facial features came to resemble the human features more and more. The ape passively receives the chemicals that change its mental states. The rise of an intelligent ape perpetuates the question of the rise of man: Is the human soul merely a manifestation of the higher quality of complex neurobiological connections in the brain that can be artificially induced by a drug, as was the case with Caesar?

Christianity advocates the existence of a human spiritual soul that has its own receptivity and inwardness, reflective moral consciousness, and creative freedom [14]. A man searches (and finds) the meaning of his being, recognizes causes of things, creates science, culture, and art - and he relates to the Absolute. In other words, he realizes himself in a relationship [15]. Thus, can such a quality of the human soul be brought about by an external substance that affects the structure of the brain to that extent that a new level of consciousness is activated?

Right after Caesar's brain is equipped with new cells, he all of a sudden becomes able to understand the injustice man has inflicted on animals, on his species. He begins to distinguish between good and evil. His strategy is to gather apes, give them the medicine and make them start fighting for their rights.

The prequel to the well-known sci-fi film Alien [16] is inspired by a similar idea: it tries to explain the origin of the parasite that needs a host for its development. The host, in this case, is the person who finds the Alien on an unknown planet. The film Alien: The Covenant [17] on the other hand presents an alternative version: a robot traveling together with the human crew created the human parasite. The robot realized his power and unleashes his egoistic desire to create something new - and, in that way, resemble the people who, in turn, created him. In the laboratory, the robot creates a monster that turns fatal to the humankind.

In his desire for a Creator-like power, man creates a new life form, a new modified virus, a bacterium, or a new animal species with the vision of curing an (up to then) incurable infection, a fierce parasite, or a competitive predator. However, all and every such creations lead to the end of human civilization.

\section{The arrogance of artificial intelligence}

In the third installment, we discuss the issue of ever-developing artificial intelligence, to the point that it could take over the world, enslave humankind or, eventually, eradicate mankind altogether, at least according some sci-fi films. The extreme case, i.e., the consequences of the human desire and naive confidence in scientific advancement without ethical reflection, is presented in the cult sci-fi film 2001: A Space Odyssey [18]: without a doubt, the film became a sci-fi classic and a modern myth about evolution, scientific development, and time-space travel.

It begins with the creation of the world, and - in its specific way - it portrays the arrival of man; for our purposes, however, the second part is more important: that is, from the point when people first confront the artificial intelligence that in the meantime has started to have its own intention with people. And even though the sequels try to justify and explain the controversial behavior of the robot, the appeal of the original remains unambiguous.

The future (that is, year 2001) seems idyllic, harmonious, without conflict - as if humanity has found a lost paradise thanks to the scientific and technological progress. In a certain way, it is a celebration of human creativity that has made a huge leap since the use of bone tools. The scenes are composed in such a way as to get the most realistic picture of the future space stations; that description is accompanied by classical music. Suggestive images of cosmic space and people conquering the universe stimulates in the viewer desire to experience such times of utopian well-being and limitless scientific and technological development. However, at least according to the storyline of 2001: A Space Odyssey, there is a catch hidden in this future paradise as well.

A black monolith appears on the moon. People explore it and consider it a major change in the history of mankind. Of course, for security reasons, everything is kept confidential. Astronauts descend to the monolith - and the background sounds connect this scene to the earlier scene, in which the apes acquire their new consciousness. The scene culminates with an unpleasant signal that visibly damages the people standing around.

And then comes the story of the space crew of Discovery 1: run by the most sophisticated computer HAL 9000; there are scientists (two in a waking state, three in hibernation) among the crew. All of sudden, HAL 9000 starts to behave in an odd way, in particular, it expresses its doubts as to the purpose of the journey. HAL detects a malfunction - but the astronauts just cannot confirm HAL's conclusion, they are not able to find the problem HAL signals. In addition, there are reports from the Earth indicating that the computer has most likely committed a diagnosis error. Nobody is ready to believe in an error: the computer is trusted blindly as the most perfect creation of mankind.

The tests in a twin HAL 9000 on Earth reveal a malfunction of the computer, but people in the control center on Earth keep saying, 'We do not believe it' [19]. The HAL 9000 computer starts messing with the feelings of both astronauts, denying the 
malfunction and insisting that the (alleged) malfunction is due to a human error.

The ubiquitous HAL is constantly watching both astronauts. They are trying to find a place out of HAL's reach, to talk about its strange behavior. In this fictional world, artificial intelligence controls people constantly - since people gave it their permission and technical means to do so. In turn, they have completely lost their privacy and, in fact, freedom to decide. The computer is ubiquitous and determines every moment of their lives.

In a sound-insulated cabin, one of the astronauts says referring to the malfunction-denying computer: 'But he was almost arrogant when he kept denying the error'. This is a problem: the computer would have lied consciously (if the backward analyses were correct). That, in turn, is a fact people either deny completely - or refuse to accept as a fact. Given the doubts, HAL is shut down and the ship is operated from Earth. Still, one of the astronauts adds: 'Well, I am not so sure what he will think about that'.

The plan did not work out. Although they were in a soundinsulated cabin, the computer was able to read their lips. That starts a fight for life, and it seems that the computer is on top of the game. Artificial intelligence - people's pride and object of a blind trust - now starts to lie first and soon it decides to kill a human being. The new autonomous form of consciousness revealed its inability of ethical reflection over its actions. Even though the computer does have absolute power over people's lives, its behavior shows that it does not have conscience; conscience thus remains a unique characteristic of humankind.

We can compare the arrogant self-confidence of the computer to the symbol of the 'beast' of the Book of Revelation (Rev 11: 7). The beast is an archetype of absolute power over man: in exchange for (apparent) earthly happiness, it requires unconditional obedience - or it pursues and kills mankind [20]. The symbol 'beast' is portrayed as artificial intelligence in the film fictional world. HAL - that is virtually ubiquitous in the film as the red light - gives one the creeps because of his control over every human action. The computer analyzes the people's mental states; it messes with them, and, should it feel threatened, it doesn't hesitate to kill them. The people in the film fictional world trust their idol blindly, and they just cannot admit its imperfection and fallacy. They are too proud of their creation. The upcoming cyber age thus can be seen as analogous to the construction of the Tower of Babel, which has caused chaos on Earth (Gn 11, 4-6); after the chaos and confusion, computers will take control over the human society.

When the crew on Discovery 1 decides to disconnect the computer (something HAL has already sensed), the whole scene gets dark - as it was at the beginning of the film. HAL then lets Frank Poole (one of the astronauts) die in space. And, the three crewmembers in the state of hibernation are killed by HAL as well.

The last crew member David Bowman asks HAL what has happened - and HAL keeps deceiving him: 'Sorry, Dave, I do not have enough information. He hides his crime as the biblical Cain who lied to God claiming that he does not know where his (murdered) brother is $(\mathrm{Gn} 4,9)$.

Astronaut David tries to disable HAL manually. Once he has succeeded, he gets the breakthrough piece of information: Only the computer knew the real destination of the spaceship. It is the proof of a thinking extraterrestrial civilization.

The part of the film we discussed points to the ethical issue: the need to keep the emerging artificial intelligence under control rather than to surrender to it blindly and leave it in full control over mankind. The already existing projects to create a supercomputer that would serve as a kind of collective brain of mankind might lead to enslavement (instead of prosperity) - or even to the destruction of mankind.

\section{Conclusion}

In this article, we have highlighted ethical concerns about the consequences of human behavior should people continue to interfere with the nature of life and persist in their desire to create a new life form and autonomous artificial intelligence: the consequences might lead to the extinction of humanity. It is the fictional film world that in a 'prophet'- like style tries to portray a society in which a feature already present in today's society is developed to the point that negative consequences ensue.

In a certain way, sci-fi films pave the way for the future. They also reveal the present ethical dilemmas related to the expected scientific and technological development. In essence, it is a warning: solve these kinds of problems so that man and mankind may move towards a better future on the planet Earth.

\section{References}

[1] Compare BLAZEJOVSKY, J.: Spirituality in Film/Spiritualita ve Filmu (in Czech). CDK, Brno, 10-18, 2007.

[2] Compare entry ,Eschatology/Eschatologie‘ (in Czech). FARRUGIA, E. (Ed.): Encyclopaedia of East Christianity/Encyklopedicky Slovnik Krestanskeho Vychodu, Refugium, Olomouc, p. 313, 2008.

[3] Compare GEISEN, H.: The Book of Revelation of Apostole John/Kniha Zjeveni Apostola Jana (in Czech). Karmelitanske nakladatelství, Kostelni Vydri, 98-105, 1999. 
[4] Compare entry, Antichrist/Antikrist' (in Czech). DOUGLAS, J. (Ed.): New Bible Dictionary/Novy biblicky slovnik. Praha, p. 31., 1996.

[5] Star Trek II: The Wrath of Khan. WERNER, N. (Dir.), USA, 1982.

[6] Star Trek X: Nemesis. BAIRD, S. (Dir.), USA, 2002.

[7] Star Trek III: The Search for Spock. NIMOY, L. (Dir.), USA, 1984.

[8] Star Trek VIII: First Contact. FRAKES, J. (Dir.), USA, 1996.

[9] Compare AA. VV.: A Short Dictionary of Sects/Maly Slovnik Sekt (in Czech). Karmelitanske nakladatelství, Kostelni Vydri, $106-$ 107, 1998.

[10] Rise of the Planet of the Apes. WYATT, R. (Dir.), USA, 2011.

[11] Planet of the Apes. SCHAFFNER, F. (Dir.), USA, 1968.

[12] Dawn of the Planet of the Apes. REEVES, M. (Dir.), USA, 2014.

[13] War for the Planet of the Apes. REEVES, M. (Dir.), USA, 2017.

[14] Compare TRESMONTANT, C.: The Main Ideas of Christian Metaphysics/Zakladni Pojmy Krestanske Metafyziky (in Czech). Aula, Praha, 53-64, 1994.

[15] Compare CORETH, E.: What is a Man?/Co je Clovek? (in Czech). Zvon, Praha, p. 155, 1996.

[16] Alien. SCOTT, R. (Dir.), UK/USA, 1979.

[17] Alien: Covenant. SCOTT, R. (Dir.), USA/UK/Australia/New Zealand/Canada, 2017.

[18] 2001: A Space Odyssey. KUBRICK, S. (Dir.), UK/USA, 1968.

[19] The author knows the film 2001: A Space Odyssey not in the English original, but in the dubbed Czech version; understandably, as he watched (and got fascinated by) the film already as a child. For that reason, the quotes he gives refer to the Czech dubbed version and are not strictly corresponding with the English script - both here and later in the section, where the quotes are given.

[20] Compare AA. VV.: The Great Inquisitor/Velky inkvizitor (in Czech). Refugium, Velehrad, 274-308, 2000. 